Maarten Rombouts

Universiteit van Zagreb

https://doi.org/10.18485/bgd_nlistiek_30.2018.ch15

\title{
DE KRAWATEN VAN LILLE
}

\section{Abstract}

This paper explores the surprising cultural contacts between the village of Lille in the northern part of Belgium and Croatia. The nickname of the inhabitants of Lille is Krawaten which has a direct etymological link to Croats (Kroaten in Dutch). The paper takes you on a journey to the seventeenth century to find out where exactly this name derives from and which connotations were associated with it. The story takes the reader back to the Eighty Years' War or Dutch War of Independence (1568-1648) between the Low Countries and the Spanish Empire. The village of Lille was at some points of that war in the frontline. The Spanish army included not only of Spanish soldiers but also many mercenaries defended the Spanish flag. Among them were some seven hundred Croatian horse riders. Furthermore the paper summarizes the research done to discover if nowadays inhabitants of Lille know their nickname and the meaning behind it.

Keywoords: Local memory, Croats, Eighty Years ' War

\section{Inleiding, motivatie en situering van het onderzoek}

Lille is een relatief kleine gemeente in het noorden van België met zo'n 16.000 inwoners en niet te verwarren met Lille (Rijsel) in het noorden van Frankrijk. Ze ligt in de Antwerpse Noorderkempen, ook wel gekend als Taxandrië. Sinds de grote fusiegolf van gemeentes in België in 1977 bestaat de gemeente Lille uit de deelgemeentes Lille, Gierle, Wechelderzande en Poederlee. Van die deelgemeentes is Lille de grootste met 5.325 inwoners en ook de oudste. De eerste vermelding van het dorp is reeds in 1123 terwijl Wechelderzande (3.862 inwoners) en Poederlee (2.820 inwoners) in 1187 worden vernoemd in documenten. Voor Gierle (4.383 inwoners) is het wachten tot 1259 (www1).Lille is een heel groene gemeente met in tegenstelling tot de rest van de Kempen nagenoeg geen industrie en al helemaal niet sinds de teloorgang van de diamantnijverheid in de regio. Met een vierde van het grondgebied bestaande uit bossen en heide heeft de gemeente een heel lage bevolkingsdichtheid. Buiten landbouw behoort natuurtoerisme tot de belangrijkste economische sector met het domein De Lilse Bergen als grootste aantrekkingspool. Dankzij de aanleg van de E34-autostrade in de jaren zeventig is de gemeente goed bereikbaar (www2).

In het kader van het thema van deze bundel, de band tussen de Lage Landen en Zuidoost-Europa, is Lille een gemeente die niet vergeten mag worden en dat heeft het dorp te danken aan zijn bijzondere bijnaam en die van zijn inwoners, zijnde het 
Krawatendorp en de Krawaten. Hoewel op het eerste zicht niet zo opvallend, word je toch overal in het dorp met die naam geconfronteerd. Er is sinds 1992 jaarlijks de Krawatencross, een cyclocrosswedstrijd die vooral populair is omdat het dorp met Wout Van Aert en Sanne Cant hofleverancier is van de Belgische (en dus wereldtop) cyclocross. Verder kan je onder de kerk een nieuw biertje ontdekken in het biercaféde Crawaett. De lokale wielrenclub heeft Krawatenwiel als geïnspireerde naam. Jaarlijks wordt de Krawatenjogging georganiseerd. Je kan er de wandeling "Van Krawaten tot Heksen" volgen en op het dorpsplein staat sinds 2011 een groot standbeeld van de uit de gemeente Lille afkomstige kunstenaar Willy Peeters met die naam.

Maar waar komt die naam nu vandaan? En hoe goed kennen de inwoners van Lille hun bijnaam en de herkomst van die bijnaam? Dat zijn de hoofdthema's van deze paper. Eerst wordt de etymologie van de bijnaam Krawaten besproken en wordt die teruggebracht tot Kroaten. Er wordt in de lokale geschiedenis gedoken en er wordt ontdekt welke betekenis en connotaties aan deze bijnaam hangen. In het tweede deel van deze paper wordt het onderzoek toegelicht naar hoe goed de inwoners van de gemeente Lille hun bijnaam kennen.

\section{Herkomst van de bijnaam Krawaten}

De bijnaam Krawaten is een rechtstreekse verbastering van Kroaten. Een tip van de sluier wordt opgelicht door het thema van het standbeeld van Willy Peeters.

Te zien zijn vier personen. Twee mensen lijken weg te vluchten terwijl de derde man en een vierde die neerligt, schijnt neer te steken. Het standbeeld verpersoonlijkt daarmee een plaatselijke legende die nog steeds gekend is en die een verklaring geeft waarom Lillenaars Krawaten worden genoemd.

[Afbeelding 1: De Krawaten, Willy Peeters, Lille]

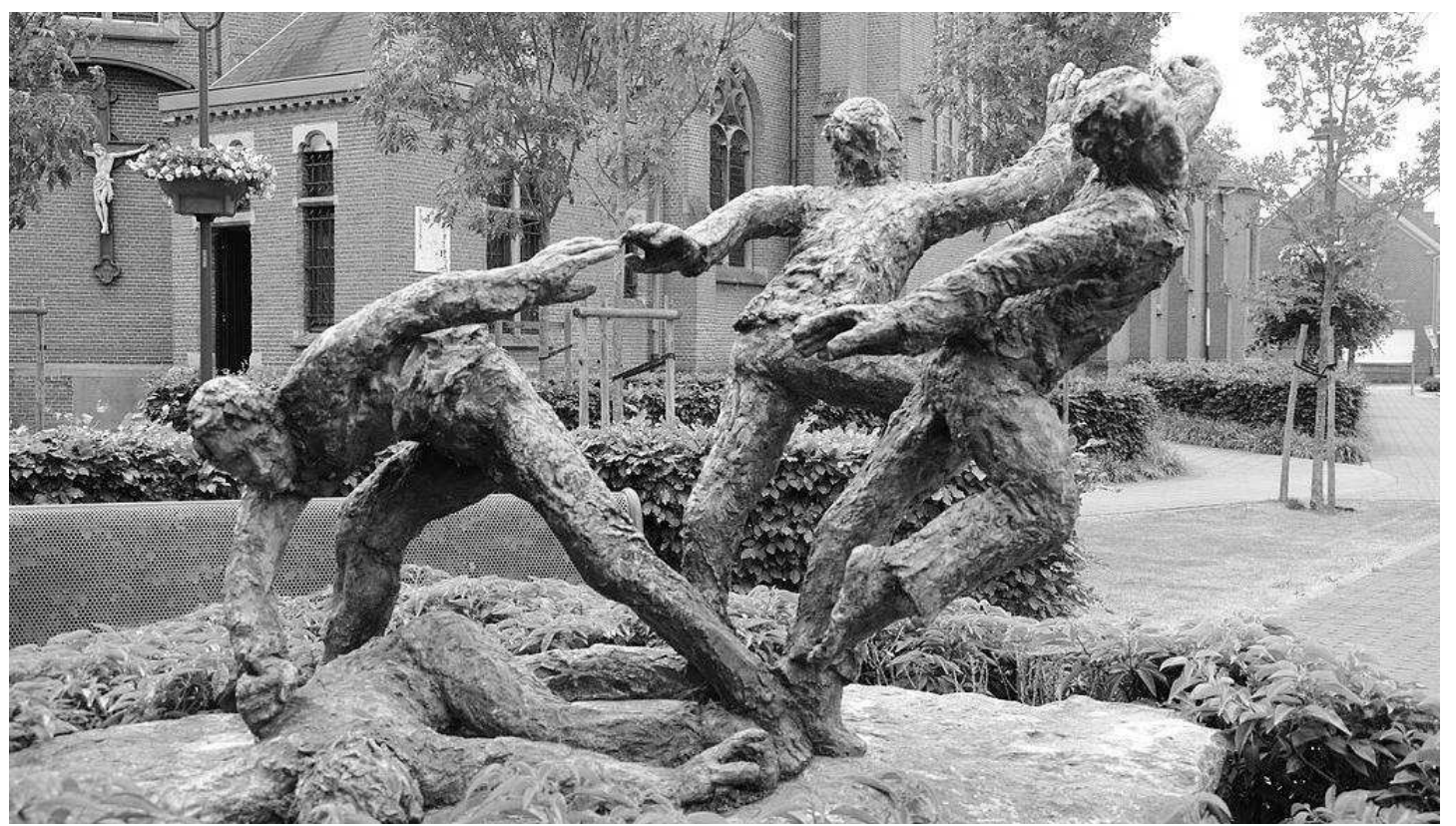




\section{De legende van de Lilse Krawaten}

Er bestaan meerdere versies van het verhaal achter deze bijnaam. De bekendste versie is volgende legende:

Een prins van Kroatië was met zijn talrijk gevolg op reis door de Kempen. De paarden van dit gezelschap waren beslagen met zilveren hoefijzers en hun wagens waren met zilveren banden belegd. Toen zij aan 'Het Valveken", een oude herberg en hoeve, kwamen welke men juist aan het opbouwen was en aangezien de prins en zijn gevolg de weg verloren waren, vroegen zij aan de metsers van "Het Valveken" de weg naar Turnhout. Deze stuurden de prins en zijn gevolg echter in de kwachten van de Zegge met de bedoeling hen te plunderen en hier rijke buit te vergaren. (www3)

Vanaf hier zijn er twee verschillende uitkomsten van het verhaal. De ene versie zegt dat de overval mislukte maar dat de Lillenaars wel de Kroatische prins vermoordden alvorens te vluchten. De andere versie meldt dat de overval lukte, dat de Lillenaars de Kroatische prins en zijn gevolg vermoordden, allen buiten een soldaat die kon wegvluchten.

Van hieruit volgen de versies van de legende opnieuw een eensluidend pad.

De vader van de prins wilde zijn zoon wreken en trok met een groot leger naar Lille om de vermetele inwoners te straffen. Reeds had hij enkele huizen aan de Laak in het gehucht Beek geplunderd en in brand gestoken, toen een processie, geleid door de pastoor met de monstrans, het leger tegemoet kwam om de vader van de vermoorde prins ootmoedig vergiffenis te smeken. De vader schonk de Lillenaars genade, maar de inwoners moesten wel een aanzienlijke geldboete als smartegeld betalen. (www3)

Nog volgens de plaatselijke legende moest het dorp tot in de negentiende eeuw een bos verkopen om deze boete te betalen.Deze legende vormt de basis van de herkomst van de bijnaam Krawaten waarbij Krawaten een onmiddellijke verbastering is van Kroaten.

\section{Het historisch onderzoek}

Maar bevat deze legende enige historische waarde? Waren er Kroatische soldaten in Lille? En zo ja, wat deden ze daar? Om een antwoord op deze vraag te geven, hebben plaatselijke historici lokale archieven uitgepluisd en ze hebben een bevestigend antwoord gevonden. De heemkundige kring van Lille heeft hier in 2012 een uitgebreid artikel over gepubliceerd met gedegen historisch bronnenonderzoek (Sas 2012: 105-175). Het jaar waarin de befaamde gebeurtenissen die de Lillenaars de bijnaam Krawaten opleverde, zich afspeelde, was 1625. De Nederlanden waren reeds een zestigtal jaren in oorlog verwikkeld met Spanje, dat soevereiniteit claimde over heel 
de regio die nu als België en Nederland bekend is, een oorlog die uiteindelijk tot resultaat had dat Nederland een onafhankelijk land werd en zo kon beginnen aan haar roemrijke geschiedenis. De Zuidelijke Nederlanden bleven aan de andere kant onder Spaans-Habsburgs bewind. Niet alleen woedde de Tachtigjarige oorlog in de regio van de Lage landen, heel Europa was in 1625 verwikkelt in een godsdienstoorlog die nu bekend staat als de Dertigjarige oorlog.

Voor dit verhaal is het Spaanse beleg van de Brabantse stad Breda in 1624 en 1625 van belang. Op dat moment waren de krijgskansen reeds volledig gekeerd. Waar in de eerste jaren van de Tachtigjarige oorlog de opstandelingen het heel erg moeilijk hadden, veranderde de situatie vanaf 1590 geleidelijk ten gunste van de Republiek van de Zeven Nederlanden. Het Spaanse rijk was in meerdere conflicten verwikkeld, onder andere met Frankrijk en had het moeilijk haar immense rijk te beheersen. Niet alleen militair was het Spaanse Rijk in de problemen, ook financieel had het het niet onder de markt waardoor bijvoorbeeld de soldij niet regelmatig betaald werd met als gevolg dat het Spaanse leger, dat overigens niet enkel uit Spanjaarden bestond, vaak aan het plunderen ging, ook onder de eigen bevolking. Maar daarover later meer.

Het uiteindelijke resultaat van het beleg van Breda zou een mijlpaal betekenen in de langdurige oorlog. Het zou immers een van de laatste keren betekenen dat een leger onder Spaanse vlag een overwinning zou boeken op wat later Nederland zou worden. Opperbevelhebber van het Spaanse leger dat het beleg rond Breda uitvoerde was de Italiaanse bevelhebber Spinola. Zijn tactiek bestond eruit om de omwalde stad Breda volledig te omsingelen zodat er niemand binnen noch buiten kon met als doel de stad uit te hongeren en haar zo tot overgave te dwingen. Daarvoor had hij een grote legermacht nodig. Schattingen maken gewag van zo'n tachtigduizend soldaten. Om het leger dat voor Breda lag te bevoorraden uit veiligere (lees zuidelijkere) gebieden, maakten de Spanjaarden gebruik van twee routes: eentje vertrok vanuit Lier en ging over Rijkevorsel (waar een kampplaats was) naar Breda. De andere vertrok vanuit Herentals (op dat moment de enige omwalde stad in de regio) over Turnhout en zo naar Breda. Speculaties zijn dat er een minder gebruikte en voor zwaar vervoer minder geschikte verbindingsweg was die dwars door het moerassige gebied van de regio tussen deze twee bevoorradingswegen sneed. Deze weg vertrok in Herentals en ging over Lille en Wechelderzande naar Rijkevorsel. Wat wel geweten is, is dat de logistieke operaties zoals bevoorradingen voornamelijk door Kroatische huurlingen werden uitgevoerd.

Zoals hoger aangehaald keerde het Spaanse leger zich geregeld tegen de lokale bevolking in de vorm van plunderingen. In die tijd bestond het systeem van sauvegardes. Dorpen of particulieren konden een vooraf afgesproken som, in de vorm van geld, levensmiddelen of goederen, betalen. In ruil daarvoor zou het dorp of de persoon die de sauvegarde betaalde tijdelijk met rust worden gelaten. Er is geweten dat Lille, dat al heel hard had geleden in de oorlog, in het voorjaar van 1625 samen met Wechelderzande zo'n sauvegarde had geregeld met de plaatselijke bevelhebber, de graaf van Anhalt die in Rijkevorsel was gelegerd. Zo kwamen in dat jaar in Wechelderzande vijf Kroatische soldaten aan, die zoals hoger vermeld vaak gebruikt werden voor logistieke operaties, om de afgesproken sauvegarde op te halen. De 
Kroatische militairen bestonden uit een jonker, twee soldaten en twee voermannen. De sauvegarde bestond uit zakken gesneden stro. Om een onbekende reden echter had de gemeentelijke secretaris de zakken met stro van Wechelderzande naar Lille gestuurd waardoor de Kroatische soldaten in het verkeerde dorp waren. Zoals hoger aangehaald was het Spaanse leger waarvan de Kroaten deel uitmaakten relatief onbekend met de verbindingsweg tussen Rijkevorsel en Herentals. Ze hadden dus een gids nodig om niet te verdwalen in de plaatselijke bossen en moerassen. Die gids was Hendrik van Trire. Onderweg kwamen ze zes boeren tegen die hulp aanboden. De boeren lokten de Kroaten echter in een hinderlaag en vermoordden hen alle zes. De gids werd gespaard op voorwaarde dat hij zou liegen over wat er gebeurd was.

In dit verhaal zitten een aantal bizarre elementen. Het meest bizarre is wel dit: hoe waarschijnlijk is het dat boeren getrainde en goed bewapende soldaten kunnen overmeesteren zonder zelf verliezen te lijden. Het roept de vraag op of dit geen geplande actie was en dat de Kroaten in de val waren gelokt. Spaanse soldaten hadden de regio al een tijdje geteisterd en onder de Spaanse soldaten hadden de Kroaten de slechtste naam. Specifiek voor Lille zijn er archiefstukken waaruit blijkt dat Kroatische soldaten eerder dat jaar ene Adrianus Van Trire hadden vermoord. Inderdaad, familie van de gids Hendrik van Trire...

\section{De connotaties die vastkleven aan de bijnaam}

Opgepast, de Kroaten komen! Het was een kreet die velen met afgrijzen aanhoorden ten tijde van de Tachtigjarige oorlog en niet alleen in de Nederlanden. Kroatische huurlingen waren tijdens de Tachtigjarige en de Dertigjarige oorlog actief in heel Europa in dienst van katholieke vorsten die streden tegen reformatorische krachten. Interessant is dat nog steeds in bepaalde delen van Duitsland en Zweden aan kleine kinderen die stout zijn geweest, wordt verteld dat ze moeten oppassen want anders komen de Kroaten (www4).

De Dertigjarige en Tachtigjarige oorlog was voor deze Kroatische militairen de eerste keer dat ze buiten hun eigen regio vochten. Jarenlang hadden ze samen met onder andere Hongaarse en Servische soldaten de buitengrens van het Habsburgse Rijk, de zogenaamde Militärgrenze ten zuiden van de Drava en de Donau, verdedigd tegen de Turken. Eind vijftiende eeuw stokte het Turkse offensief en geleidelijk aan kwamen deze Kroatische soldaten, voornamelijk ruiters, als huurlingen terecht in het keizerlijke Habsburgse leger en dus ook in het Spaanse Habsburgse leger. Geschat wordt dat er niet meer dan een zevenhondertal van deze Kroatische ruiters in de Lage Landen waren ingezet. Gehard door de strijd tegen de Turken hadden de Kroatische soldaten hun eigen methoden van oorlogsvoering ontwikkeld. Een methode die vaak neerkwam op het uitputten van de vijand op eigen grondgebied door middel van plundering. Deze ervaring in combinatie met het vaak niet of te laat betalen van hun soldij, leidde ertoe dat ze ook op eigen grondgebied aan het plunderen gingen. Het gevolg was dat deze Kroatische ruiters, steeds herkenbaar aan hun typische sjaal, bij de plaatselijke bevolking het imago kregen van uiterst gewelddadig. Deze reputatie is 
duidelijk te zien in allerlei documenten uit die tijd of uit deze dichtregel van Joost van den Vondel uit 1627: 'De krabbende Krabat, voor duyveluytgepickt, Wiens scharpe sabel hackt, wiens naere kreet verschrickt.'(www5)

Die slechte reputatie van de Kroatische ruiters heeft een ingang gevonden in het taalgebruik. Het woord krawaat is opgenomen in het Woordenboek der Nederlandsche Taal en in het Vlaams Woordenboek. De eerste woordverklaring voor krawaat in het Woordenboek der Nederlandsche Taal is heel neutraal en verwijst naar de historische militaire achtergrond.

Een bewoner van Kroatië. In het keizerlijke leger dienden vroeger als ruiters een aantal Kroaten, (die zich door hunne woestheid berucht maakten), en vandaar werd de naam ook toegepast op afdeelingen lichte ruiterij in andere legers, met name in het Fransche. (www6)

Het is inderdaad zo dat tot in de negentiende eeuw het Franse leger een Kroatische divisie in de ruiterij had. Uit de tweede betekenis van het woord krawaat in het Woordenboek der Nederlandsche Taal is de negatieve reputatie van het Kroatisch leger te zien:

Door den slechten naam waarin de Kroatische soldaten stonden werd het woord (ook in den vorm krawat en karwat) in Antwerpen en omgeving een scheldwoord; men bezigt het voor een deugniet of voor iemand die niet deugt voor zijn werk, en ook in minder ongunstigen zin voor een fopper of plaaggeest, of voor een halven gek. (www6)

In het Vlaams Woordenboek wordt dat 'deugniet, kwajongen' (www7). Ook in het Zweeds bestaat dit woord overigens in de vorm van krabat en heeft dezelfde betekenis en etymologie als het Nederlandse woord krawaat (www8). Zoals verder in deze paper zal blijken, is in het Nederlands noch het woord krawaat heel erg bekend of gebruikt en noch minder gekend is de oorspronkelijk zeer negatieve connotatie.

De etymologie van de bijnaam Krawaten vormde voor de onderzoeker een interessante extra onderzoeksvraag, vooral na het ontdekken van een anekdote specifiek voor Lille. Het verhaal wil dat de schrijver Hendrik Conscience op een bepaald moment neerstreek in Lille. Zijn grootmoeder zou afkomstig zijn uit de buurgemeente van Lille, Oostmalle en zo zou hij bekend zijn geweest met de legende van de Lilse Krawaten. Sommige Lilse bronnen vermelden dat de bekende schrijver dat verhaal op papier wou zetten. De toenmalige burgemeester van Lille protesteerde echter met klem tegen dat plan aangezien het verhaal van de Lilse Krawaten hem met schaamte vervulde (www3).

Wat voorlopig alvast duidelijk is, is dat inwoners van Lille de bijnaam Krawaten hebben gekregen door een gebeurtenis tijdens de Tachtigjarige oorlog waarbij Kroatische soldaten in de regio huishielden. Ook is duidelijk dat er rond die bijnaam een negatieve waas hangt die gebaseerd is op de gebeurtenissen (moord op Kroatische soldaten) en op de reputatie van de Kroatische soldaten tijdens die Tachtigjarige oorlog. Deze negatieve connotatie wordt weerspiegeld in het niet zo 
bekende woord krawaat en in de oorspronkelijke schaamte over de bijnaam in Lille zoals de anekdote rond Conscience laat zien.

\section{Het onderzoek}

In het kader van de conferentie Drie decennia Belgradose Neerlandistiek werd een onderzoek gedaan naar de hedendaagse kennis bij inwoners uit Lille en de deelgemeenten naar de bijnaam van Lillenaars. In de eerste plaats vroeg de onderzoeker zich af of de inwoners uit Lille en haar deelgemeenten de bijnaam van Lillenaars kennen. Bijkomende onderzoeksvragen bij deze eerste hoofdvraag waren of er verschillen zijn in de kennis omtrent de bijnaam tussen het dorp Lille en de deelgemeenten van de gemeente Lille. Verder werd gekeken naar factoren die mogelijke verschillen in de kennis kunnen verklaren zoals leeftijd en hoe lang respondenten in de gemeente wonen. De tweede hoofdvraag focuste op de herkomst van deze bijnaam. Kennen mensen het verhaal achter de bijnaam of enkel de legende? Of misschien geen van beide? Het derde facet dat aan bod kwam is de (oorspronkelijk) negatieve connotatie die aan het woord krawaten en aan de bijnaam Krawaten hing. Ervaren inwoners van Lille hun bijnaam als iets dat negatief is of is die negatieve band met het woord verdwenen?

\section{De methode}

De vragenlijst werd opgesteld in Google Forms in verschillende secties die afhankelijk van de antwoorden in de voorgaande sectiesal dan niet werden opengesteld. In de eerste sectie werd gevraagd of de respondent in de gemeente Lille woont of heeft gewoond. Indien het antwoord negatief was, werd de vragenlijst voor die respondent afgesloten. Bij een positief antwoord werd verder gegaan naar de volgende sectie waarin naar de eerste hoofdvraag werd gepeild. Als het antwoord op de vraag of de respondent de bijnaam van inwoners van Lille kent negatief was, werd de respondent doorgestuurd naar de sectie waarin een aantal persoonlijke gegevens werden gevraagd. Bij een instemmend antwoord werd vervolgens gevraagd wat de bijnaam van de inwoners van Lille is en waar deze bijnaam vandaan komt. Hiermee is de tweede hoofdvraag aan bod gekomen. Vervolgens werd onderzocht of de respondenten de bijnaam Krawaten al in een andere context heeft horen gebruiken dan louter als bijnaam en zo ja in welke context. Tot slot werd heel concreet gevraagd of de bijnaam een positief of negatief gevoel opwekt bij de respondent. De laatste drie vragen probeerden de derde hoofdvraag te beantwoorden.

Het vinden van een representatief staal respondenten bleek niet zo moeilijk als in eerste instantie was gedacht. De onderzoeker is afkomstig uit de gemeente Lille en heeft er nog een netwerk. Eveneens bestaat er een heel actieve Facebookgroep van de gemeente waar de onderzoeker de vragenlijst kon verspreiden. Op deze twee manieren werd de vragenlijst bekend gemaakt. Tijdens de week dat de vragenlijst toegankelijk was, werd hij door 327 personen ingevuld. Van die 327 waren er 326 afkomstig uit Lille. 
Het profiel van de respondenten

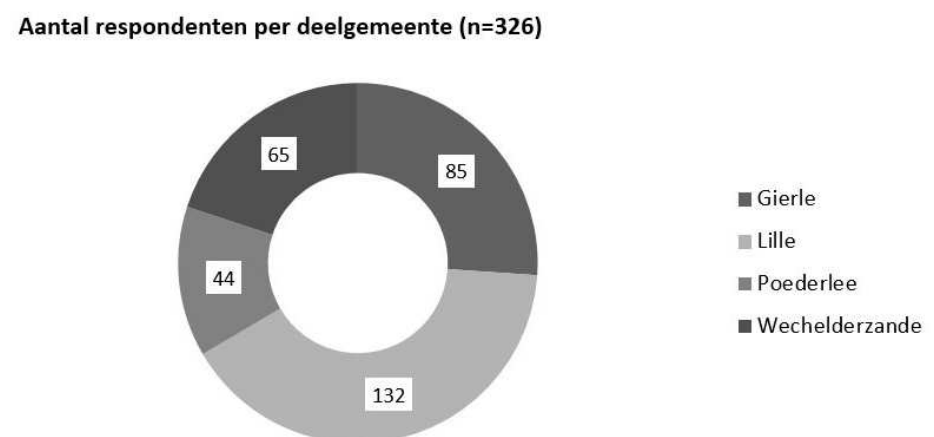

[Grafiek 1: Aantal respondenten per deelgemeente (eigen bewerking)]

Zoals blijkt uit grafiek 1 wonen of hebben de meeste respondenten, 40\% (132 personen) in het dorp Lille gewoond. $26 \%$ van de respondenten ( 85 personen) is afkomstig uit Gierle, 20\% (65 personen) uit Wechelderzande en de resterende 14\% (44 personen) is woonachtig in Poederlee, de kleinste van de vier deelgemeenten.

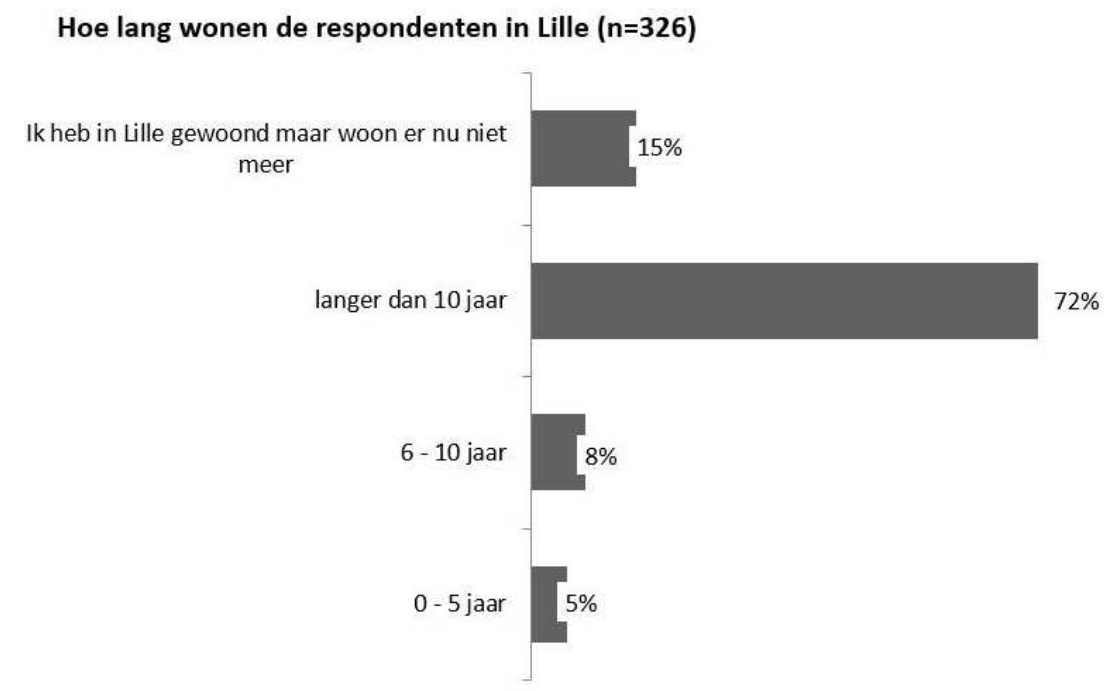

[Grafiek 2: Hoe lang wonen de respondenten in Lille (eigen bewerking)]

Het overgrote deel van de respondenten woont nog steeds in de gemeente Lille. Slechts $15 \%$ heeft er gewoond maar woont er nu niet meer. Van de overige $85 \%$ woont het leeuwendeel reeds langer dan tien jaar in Lille. Een minderheid woont er minder lang met $8 \%$ die er tussen zes en tien jaar woont en 5\% die er minder lang dan 5 jaar woont. 


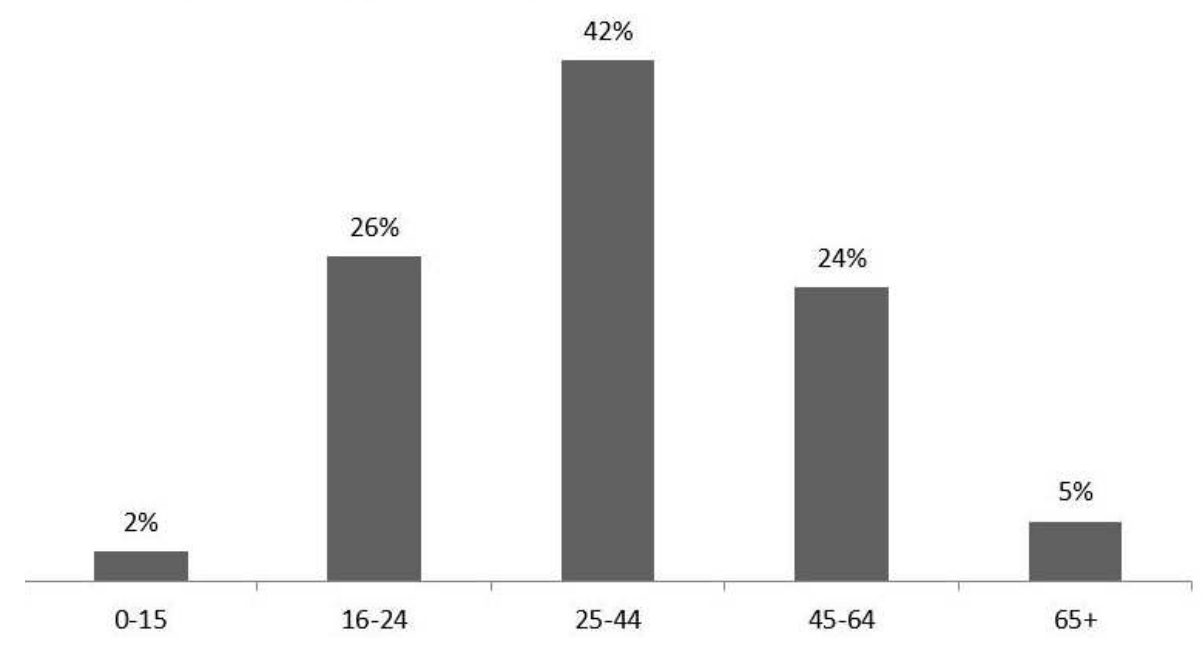

[Grafiek 3: De leeftijd van de respondenten (eigen bewerking)]

Als er wordt gekeken naar de leeftijd van de respondenten vertoont de grafiek een normale leeftijdscurve met een minderheid jonger dan 16 of ouder dan 65 jaar oud wat betekent dat de meerderheid van de respondenten gesitueerd is in de actieve bevolking.

De eerste hoofdvraag: Hoe is het gesteld met de kennis van de bijnaam van Lillenaars? In eerste instantie antwoordde $61 \%$ van de respondenten dat ze de bijnaam van de inwoners van Lille kennen. Bij nader onderzoek bleek dat dit resultaat uitgezuiverd moest worden. Een aantal respondenten had geantwoord dat ze de bijnaam kenden maar vulden bij de volgende vraag een verkeerde bijnaam in. Sommigen gaven de bijnaam van een andere deelgemeente dan Lille, anderen alludeerden aan een andere lokale legende. Het uiteindelijke resultaat is dat $56 \%$ of 183 personen de correcte bijnaam Krawaten kent.

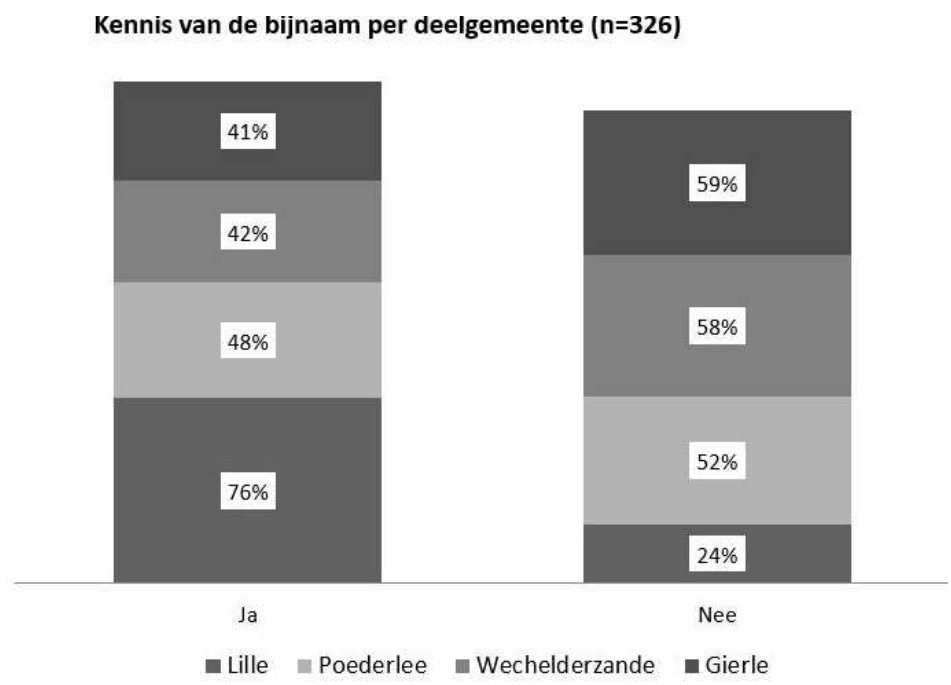

[Grafiek 4: Kennis van de bijnaam per deelgemeente (eigen bewerking)] 
Uitgesplitst per deelgemeente is het opvallend dat het vooral inwoners van het dorp Lille zijn met $76 \%$ die hun eigen bijnaam kennen. In de drie andere deelgemeenten ligt de kennis van de bijnaam Krawaten aanzienlijk lager. Noch in Gierle, Wechelderzande of Poederlee kent de helft de bijnaam van Lillenaars. Op het eerste zicht is dit niet zo wonderbaarlijk en suggereert dit resultaat dat de onderlinge band tussen de deelgemeenten niet zo groot is, maar dat is slechts speculatie.

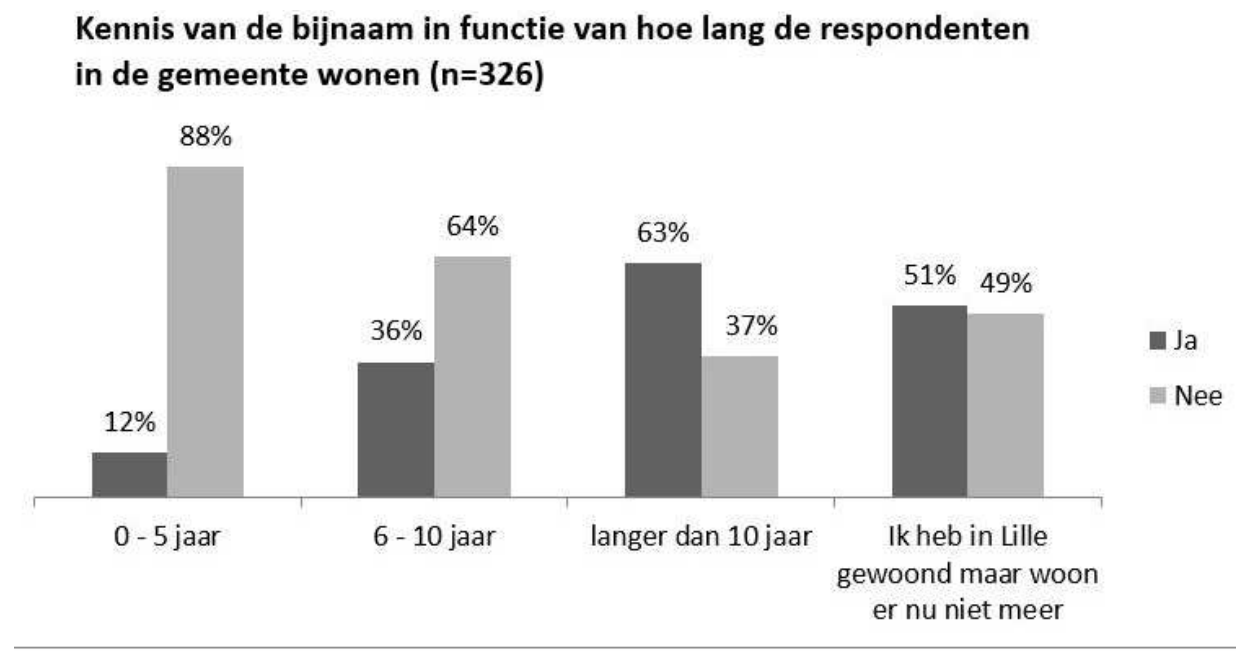

[Grafiek 5: Kennis van de bijnaam in functie van hoe lang de respondenten in de gemeente wonen (eigen bewerking)]

Gekeken naar de andere factoren is te zien dat de kennis van de bijnaam heel erg afhankelijk is van hoe lang de respondent in de gemeente Lille woont. Van degenen die er minder dan vijf jaar wonen, kent slechts $12 \%$ de bijnaam. Dit percentage groeit rechtevenredig met het aantal jaren dat de respondent in de gemeente Lille woont waarbij de meerderheid van mensen die langer dan tien jaar in Lille wonen de bijnaam kent.

Kennis van de bijnaam in functie van leeftijd $(n=326)$

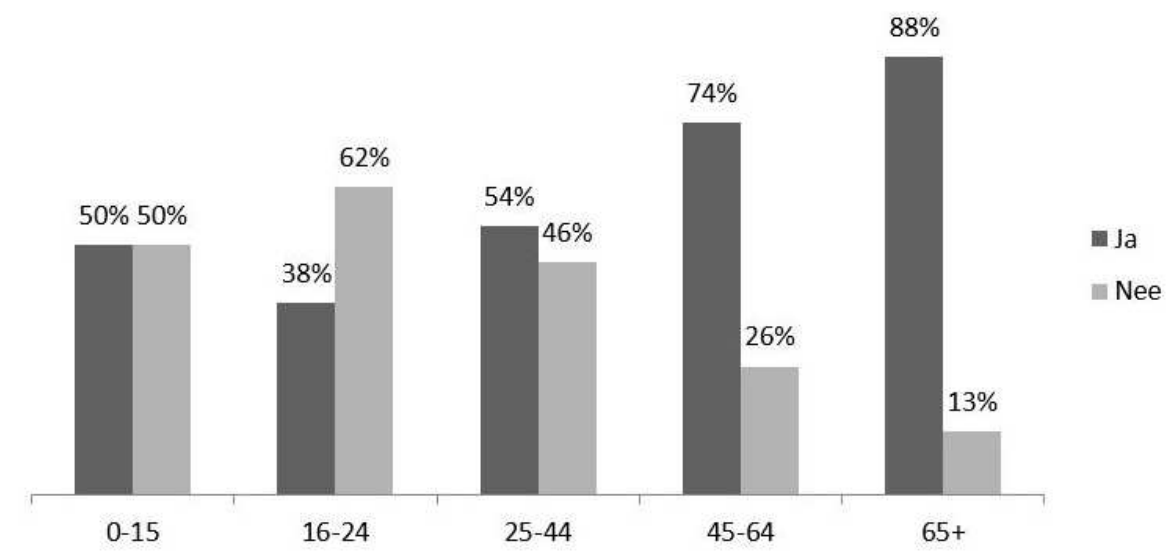

[Grafiek 6: Kennis van de bijnaam in functie van leeftijd (eigen bewerking)] 
Als de kennis over de bijnaam van Lillenaars wordt vergeleken met de leeftijd van de respondenten zijn er weinig verrassingen te noteren. Hoe ouder, hoe hoger de kans dat respondenten de bijnaam Krawaten kennen. De enige leeftijdscategorie die deze curve niet aanhoudt, is die tussen 16 en 24 jaar oud. Personen in die leeftijdscategorie scoren beduidend slechter dan hun jongere dorpsgenoten. Een mogelijke verklaring had kunnen zijn dat in deze leeftijdscategorie meer recente migratie was waardoor personen in deze leeftijdscategorie minder lang in Lille wonen dan respondenten in andere categorieën. Dat bleek echter een foutieve assumptie te zijn. Het verschil is uit de beschikbare gegevens niet te verklaren.

Hoewel de officiële schrijfwijze van de bijnaam Krawaten is, bleek uit de resultaten van het onderzoek dat die schrijfwijze niet zo vast ligt als werd gedacht. De respondenten waren heel creatief wat resulteerde in een myriade aan verschillende manieren waarop de bijnaam werd geschreven. De grote meerderheid (159) hield het wel bij de schrijfwijze met een $\mathrm{k}$ in al haar varianten (Krawaat, Krawaatje). Sommigen (9) verkozen een meer archaïsche schrijfwijze Crawaet zoals in de archiefdocumenten is te zien. Een uiterst kleine minderheid van de respondenten (8) spelde de bijnaam met een combinatie van een meer archaïsche schrijfwijze en een moderne schrijfwijze met ofwel het gebruik van het verouderde ae of het gebruik van een c in plaats van een k. Dat werd dan Krawaet of Crawaat. Opvallend is dat er respondenten waren die in de schrijfwijze van de bijnaam reeds een link leggen met de herkomst van het woord in de vorm van Croawaten, Kroaten, Krowaten.

De tweede hoofdvraag: Hoe is het gesteld met de kennis over de herkomst van de bijnaam Kroaten

In de vragenlijst was dit een open vraag waardoor de informatie moeilijker te verwerken was door het verrassend grote aantal respondenten. De vraag werd enkel beschikbaar gesteld aan diegenen die positief antwoordden op de vraag of ze de bijnaam van inwoners van het dorp Lille kennen. Dit kwam overeen met 183 respondenten of $56 \%$ van alle respondenten.

Om de gegevens overzichtelijk te presenteren, is er verkozen om de antwoorden in drie verschillende categorieën op te delen. In de eerste categorie vallen de respondenten die zelf aangeven dat ze geen idee hebben waarop de bijnaam van Lillenaars rust. In de tweede categorie zijn verklaringen van de bijnaam opgenomen waaruit blijkt dat de respondent geen weet heeft van het feit dat de bijnaam rechtstreeks gelinkt is aan Kroatië. De derde categorie zijn die verklaringen waarbij de herkomst van de bijnaam Krawaten op een of andere manier wordt verbonden met Kroatië. 
Verband tussen Kroatie en de bijnaam Krawaten?

( $n=183$ )

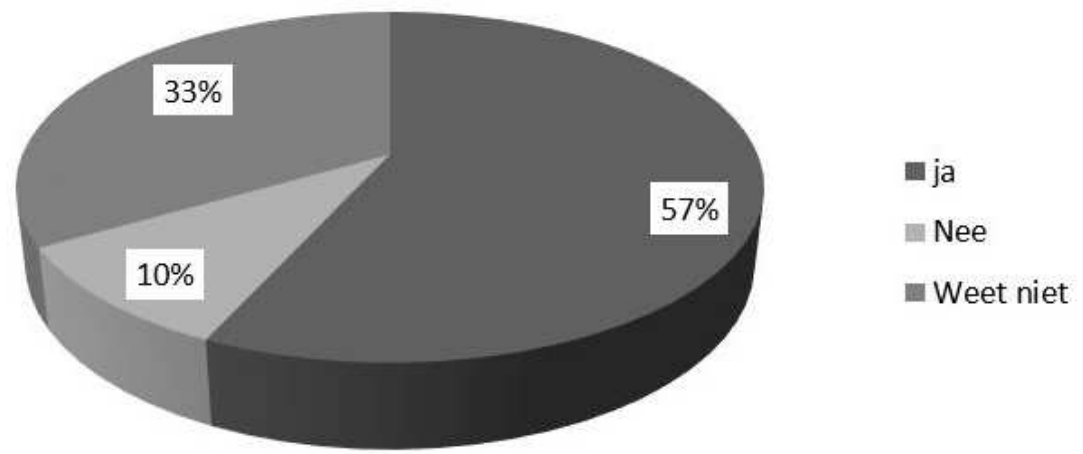

[Grafiek 7: Leggen de respondenten het verband tussen Kroatie en Krawaten? (eigen bewerking)]

Zoals uit de grafiek blijkt, heeft een derde van de respondenten die de bijnaam Krawaten kent geen enkel idee waar de bijnaam vandaan komt. 10\% van hen geeft een verklaring die niets met Kroatië te maken heeft. De meeste in deze categorie weten wel dat het iets te maken heeft met een overal, een moord of een oorlogssituatie maar kunnen de exacte herkomst van het woord niet aangeven en kunnen dus geen verband leggen met de Kroatische oorsprong van het woord krawaten. Opvallend is wel dat vijf respondenten meenden dat de bijnaam komt van de afgeleide betekenis van het woord krawaat, namelijk deugniet. Voor hen zijn Lillenaars dus deugnieten. Het meest verrassende antwoord in deze categorie is dat een respondent ervan overtuigd is dat het woord krawaat harde werker betekent.

Meer dan de helft van de respondenten die de bijnaam kent, kan een link leggen met Kroatië als oorsprong van de bijnaam. Dat komt overeen met $31 \%$ van alle respondenten die de vragenlijst invulden. De meeste van hen hebben een vage notie van de legende maar nooit van de volledige legende. In hun antwoorden komen fragmenten terug die op de legende terug te brengen zijn. Zo kunnen ze zich iets van een overval of moord op een Kroatische prins of Kroaten in het algemeen herinneren. Een respondent herinnert zich het deel waarbij Lille een bos heeft moeten verkopen om de schuld te betalen. Anderen komen met hun antwoord dichter bij de historische feiten. Zo weten een aantal respondenten dat er ooit in Lille Kroaten zijn geweest en sommigen geven aan dat die Kroaten daar waren om te vechten. Een respondent wist zelfs dat het over Kroatische huurlingen ging. Een exacte datering echter kon bijna niemand geven. Een respondent plaatste de gebeurtenissen in de zeventiende eeuw.De dichtstbijzijnde andere antwoorden zijn "in de middeleeuwen" en "een paar eeuwen geleden". In deze categorie is het meest verrassende antwoord dat van de respondent die dacht dat het over een Joegoslavisch leger ging. 
De derde hoofdvraag: blijft er nog iets over van de negatieve connotatie rond het woord Krawaten?

Zoals hoger vermeld, kleven er aan het woord krawaten en aan de bijnaam Krawaten een aantal negatieve connotaties. De eerste gaat rechtstreeks terug naar de slechte reputatie van Kroatische huurlingen tijdens de Tachtigjarige oorlog. Vanuit die etymologie betekent het woord krawaat een deugniet zoals nog te zien in de lokale uitdrukking 'A ge me zo'n krawaten op schok zijt, kan het wel eens voorvallen dat ge ambras krijgt.' Vrij vertaald betekent dit: 'Als je met zo'n krawaten op stap bent, is het niet uitzonderlijk dat je problemen krijgt'. Verder specifiek voor Lille is er nog de negatieve connotatie dat de bijnaam teruggaat op een historische gebeurtenis waar het moeilijk is trots op te zijn. Het gaat uiteindelijk over moord in koelen bloede. Nog meer specifiek duidt de anekdote rond Hendrik Conscience, of ze nu waar is of niet, erop dat er in Lille op een bepaald moment toch een zekere gêne bestond omtrent haar bijnaam.

Om er achter te komen hoe Lillenaars tegenwoordig aankijken tegen hun bijnaam werd er in de eerste plaats gevraagd of ze het woord krawaten al in een andere context hebben horen gebruiken. Die context zou een eerste aanduiding betekenen. Van de 183 respondenten die bekend zijn met de bijnaam Krawaten, heeft iets meer dan de helft het woord krawaten al in een andere context horen gebruiken. De meeste referentie gaan over de inleiding genoemde Krawatencross, het plaatselijke cafe en andere lokale handelszaken en organisaties. In deze gevallen keken de respondenten eerder neutraal tot positief aan tegenover de bijnaam Krawaten.

Interessant is dat acht respondenten het woord krawaten ook kennen in de betekenis van deugniet of iets pejoratiever als onguur type. Opvallend is dat vijf respondenten hieraan een positieve betekenis hechten: 'Deugniet, maar wel plezant'. Twee verwijzen naar een lokale uitspraak: 'Gij zijt nen echte krawaat.' Enkel de respondent die het woord krawaat als deugniet kent en die het vereenzelvigd met een onguur type heeft er een negatieve associatie bij.

Een respondent ten slotte associeert het woord krawaten met inwoners van Kroatië en heeft daar een positief gevoel bij.

Wordt er in het algemeen gekeken naar de gevoelens die de bijnaam Krawaten bij de inwoners van de gemeente Lille oproept dan valt op dat de oorspronkelijke negatieve connotatie volledig verdwenen is. Slechts bij $2 \%$ van de respondenten roept de bijnaam negatieve gevoelens op en deze zijn afkomstig uit de deelgemeenten Wechelderzande en Gierle. In het dorp Lille en in Poederlee, dat geografisch meer een eenheid met Lille vormt, zijn er geen negatieve gevoelens tegenover de bijnaam. 


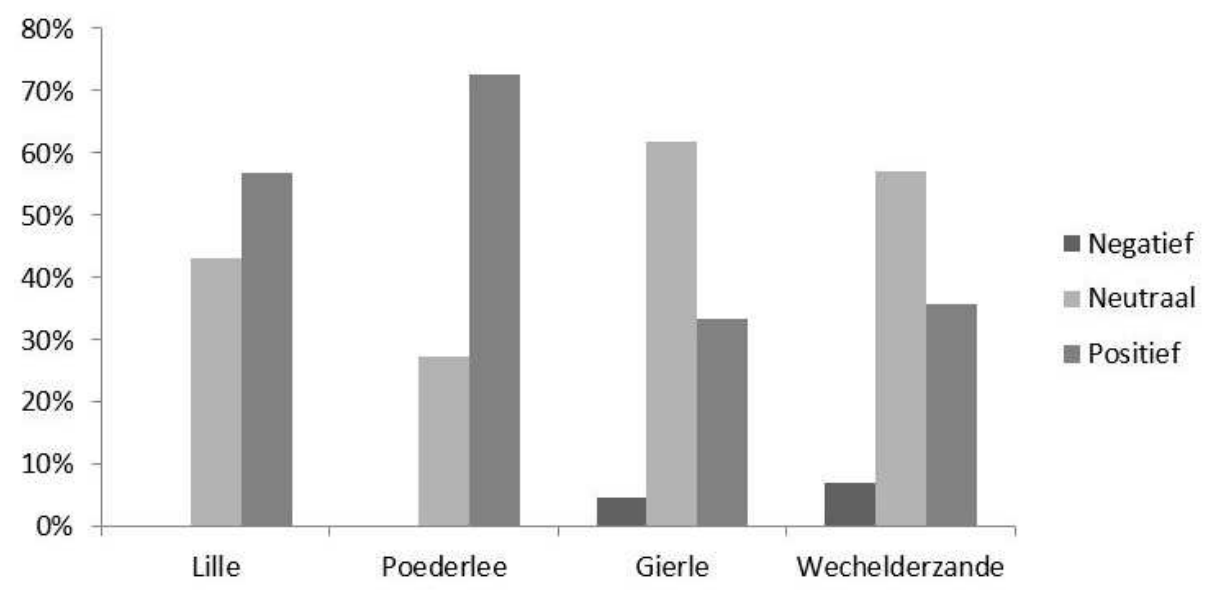

[Grafiek 8: Emotionele waarde t.a.v. de bijnaam Krawaten opgesplitst per deelgemeente (eigen bewerking)]

Uit de grafiek is ook af te lezen dat inwoners van Lille en Poederlee de bijnaam Krawaten veel positiever ervaren dan in de verder afgelegen deelgemeenten Gierle en Wechelderzande. De respondenten afkomstig uit Poederlee hechten proportioneel een positievere connotatie aan de bijnaam dan de respondenten uit Lille zelf. Een uitleg hiervoor kan niet gegeven worden.

\section{Besluit}

Deze paper belichtte een interessante en misschien zelfs verrassende band tussen Zuidoost-Europa en de Lage Landen. De inwoners van het kleine dorp Lille in de Antwerpse Noorderkempen hebben de bijnaam Krawaten. Etymologisch is deze bijnaam volledig terug te voeren op Kroatische soldaten die in de regio anwezig waren tijdens de Tachtigjarige oorlog in de zeventiende eeuw. In het dorp is er een relatief bekende legende aanwezig die een verklaring biedt waarom inwoners van Lille de bijnaam Krawaten hebben. Historisch onderzoek heeft uitgewezen dat achter deze legende een bron van waarheid schuilgaat. Kroatische soldaten in die periode hadden een slechte reputatie. Dat verklaart waarom het woord krawaten in het Nederlandse taalgebruik is binnengesijpeld als een benaming voor iemand die allerlei streken uithaalt of erger, een bandiet. Met deze paper wilde de onderzoeker nagaan hoe het gesteld is met de kennis van de bijnaam Krawaten onder de inwoners van de gemeente Lille die bestaat uit de deelgemeenten Lille, Gierle, Wechelderzande en Poederlee. Met behulp van een online vragenlijst die door 326 personen uit de gemeente Lille is ingevuld, wat overeenkomt met bijna twee procent van de bevolking, is ontdekt dat iets meer dan de helft van de inwoners van de gemeente Lille de bijnaam van de inwoners van het dorp Lille kennen. Grote verschillen waren waar te nemen tussen het dorp Lille, waar drie vierde de bijnaam kent en de andere deelgemeenten. Hoe langer 
mensen in de gemeente Lille wonen, hoe groter de kans dat ze de bijnaam kennen. Hetzelfde gaat op voor de leeftijd. Hoe ouder mensen zijn, des te beter kennen ze de bijnaam met de uitzondering van de leeftijdscategorie 16-24 die de bijnaam minder goed kennen dan hun jongere dorpsgenoten.

Verder is onderzocht of die mensen die de bijnaam kennen ook op de hoogte zijn van de herkomst van die bijnaam en vooral of ze zich bewust zijn van de bijzondere connectie met Kroatië. 31\% van de respondenten is op de hoogte van het cultuurcontact tussen Lille en Kroatië. De kennis reikt meestal niet verder dan een vage afspiegeling van de lokale legende maar er is toch enige verbondenheid met Kroatië.

Tot slot werd er dieper ingegaan of de oorspronkelijke negatieve connotatie die hing rond het woord krawaten en dus rond de bijnaam Krawaten geëvolueerd is. Het antwoord op die vraag is ronduit ja. Met slechts $2 \%$ van de respondenten die de bijnaam van de inwoners van het dorp Lille kennen die de bijnaam als negatief evalueren, kan er geconcludeerd worden dat van de oorspronkelijke negatieve connotatie niet veel meer over is gebleven.

\section{Literatuuropgave}

Sas, B., W. Van den Branden en N. Paepen. 2012. 'De Lillenaren en die Crawaeten tijdens de tweede helft van de Tachtigjarige Oorlog'. Jaarboek Heemkundige Kring Norbert De Vrijter - Lille 2012, pp. 105-175.

\section{Internetbronnen}

www1

Geschiedenis (van Lille). Geraadpleegd op 9 februari 2018, van https://www.lille.be/ Geschiedenis/default.aspx?id=284

www2

Lille voorgesteld. Geraadpleegd op 9 februari 2018, van https://www.lille.be/Lille\%20 voorgesteld/default.aspx?id=283

www3

De Krawatenhistorie van Lille. Geraadpleegd op 9 februari 2018, van https://www.lille. be/product.aspx?id=116

www4

AcademiaCravatica, Kravat pukovnija - odutemeljenja do danas. Geraadpleegd op 9 februari 2018, van http://www.kravatpukovnija.com/o-nama/ 
www5

Van den Vondel, Joost. 1627. I.V. Vondelens Verovering van Grol, door Frederick Henrick, Prince van Oranje. Geraadpleegd op 9 februari 2018, van http://www. dbnl.org/tekst/vond001dewe03_01/vond001dewe03_01_0006.php

www6

Instituut voor de Nederlandse taal. 2010. Historische woordenboeken op internet. Geraadpleegd op 9 februari 2018, van http://gtb.inl.nl/

www7

Het Vlaams Woordenboek. 2017. Krawaat.Geraadpleegd op 9 februari 2018, van http://www.vlaamswoordenboek.be/definities/term/krawaat

www8

Larsson, Håkan. 2008. On Linguistic Warfare. Dissident Voice. Geraadpleegd op 9 februari 2018, van https://dissidentvoice.org/2008/05/on-linguistic-warfare/ 